\title{
Detection Of Antibiotic Residues In Chicken Eggs At The Chicken Egg Farmers And Egg Distributors On Trading Business In Denpasar Municipality
}

\author{
Maria Clafita Witoko' ${ }^{1}$ I Wayan Suardana ${ }^{2}$, Mas Djoko Rudyanto ${ }^{2}$. \\ ${ }^{1}$ Veterinary Medicine Student, ${ }^{2}$ Department of Veterinary Public Health \\ Faculty of Veterinary Medicine, Udayana University \\ PB Sudirman, Denpasar, Bali, Indonesia 80234 \\ Tel: +62 $361223791 ;$ Fax: +62 362223791 \\ *Corresponding author: clafitawitoko@gmail.com
}

\begin{abstract}
Antibiotic residues often found in food animal due to antibiotic usage for prevention and medication of diseases in livestock. The usage of antibiotics as growth promoter also often done by farmers to increase feed efficiency and enhance livestock's growth, producing larger and heavier livestock that are more profitable. Food animal that contains antibiotic residues are neither safe nor qualified as human consumption. The objective of this research was to detect antibiotic residues in chicken eggs at chicken egg farmers and egg distributors in Denpasar, Bali. In order to determine antibiotic residues, a total of 24 chicken egg samples were randomly collected from farmers and distributors, followed by testing with bioassay method. The result showed that 13 out of 18 samples collected from farmers and 1 out of 6 samples collected from distributors were tested positive for antibiotic residues. Most of the tested positive samples contained aminoglycosides residue $(66.7 \%$ on eggs collected from farmers), followed by tetracycline residue (44,4 on farmers egg and $16,7 \%$ on distributors egg) and macrolide residue (16,7\% on farmers egg).
\end{abstract}

Keywords: antibiotic residues, food safety, food security, AMR

\section{INTRODUCTION}

Animal protein is important for human health because of its amino acid that composes the protein that needed by human [1]. Egg is more affordable compared to meat and are easily obtained; thus, egg is an animaloriginated food that has become main source of protein for human. Animal food products that are not well managed can harm human health, known as hazard in food that can threaten animal food safety such as animal diseases, food borne diseases, and chemical contamination like antibiotic residues [2].
Antibiotic residues often found in food animal due to antibiotic usage for prevention (prophylactic purpose) and medication of diseases in livestock. The usage of antibiotics as growth promoter also often done by farmers to increase feed efficiency and enhance livestock's growth [3]. Food animal that contains antibiotic residues are neither safe nor qualified as human consumption. The use of antibiotics carried out by farmers raise worry among the public health for the accuracy of the dosage and withdrawal time is not guaranteed, resulting the deposition of antibiotics in animal tissues [3]. Antibiotic residues can be found in 
all animal food products including egg and milk [4].

Antibiotic residues can cause pathological effects in human health such as allergy reaction, carcinogenetic, autoimmunity, mutagenicity, hepatotoxicity, reproductive disorders, bone marrow toxicity, nephropathy, immunopathological effects, and transfer of antibiotic resistant bacteria to the human [4]. According to European Centers for Disease Control (ECDC), approximately 25,000 people died from pathogens that are resistant to antibiotics. Whereas in Indonesia, according to the Ministry of Health of the Republic of Indonesia, the mortality rate due to antibiotic resistance until 2014 amounted to 700,000 mortality per year. The danger posed by antibiotic resistance is also influential in the economy, namely the rejection of meat exports to foreign countries, which affect the economies of exporting countries [5]. Antibiotic residues can occur at the farmer level and continue to be carried in the eggs circulating in the market, therefore this antibiotic residue research is carried out.

\section{RESEARCH METHODS}

\section{Egg Sampling Procedures}

This research used Golden Comet chicken eggs. The number of samples used in this study was 24 egg samples. Samples were taken from 3 farmers in Tabanan district, Bali, Indonesia and 3 chicken egg distributors who distributed the eggs in the city of Denpasar. A sample consisting of four one-day-old eggs were randomly collected from each farmer on the $1^{\text {st }}, 7^{\text {th }}$, and $14^{\text {th }}$ day and once more repeated after the first cycle collection completed. Differ from the farmers; egg samples collected from distributors were taken within 2 weeks, where 1 sample collected from each distributor per week.

\section{Bioassay Screening Test}

Bioassay screening test (SNI 7424:2008) represented four classes of antibiotics, namely Penicillin, Tetracycline (oxytetracycline), Aminoglycoside (kanamycin), and Macrolide (tilosin). Each class of antibiotics used different bacteria, agar medium ingredients, and incubation temperatures. The test considered positive when the surface surrounding the paper disc containing the test solution is clear. This test was performed triple where two coincident results considered positive. Details are described in Table 3.

\section{Sample Preparation}

The egg sample was weighed up to as much as $10 \mathrm{~g}$ then added $20 \mathrm{ml}$ phosphate buffer no. $2\left(6,4 \mathrm{~g} \mathrm{KH}_{2} \mathrm{PO}_{4}\right.$ and 18,9 $\mathrm{g} \mathrm{Na}_{2} \mathrm{HPO}_{4}$ mixed with distilled water to attain $1000 \mathrm{ml}, \mathrm{pH}$ set to $7.0 \pm$ 0,1 ), homogenized using a homogenizer and then centrifuge $3,000 \mathrm{rpm}$ for 10 minutes. The supernatant was taken and used as a test solution.

TABLE 3. COMPOSITION OF BIOASSAY THAT PERFORMED

\begin{tabular}{|c|c|c|c|}
\hline Bioassay & Bacteria Test & $\begin{array}{c}\text { Agar } \\
\text { Medium }\end{array}$ & Incubation \\
\hline $\begin{array}{l}\text { Penicillin } \\
\text { (penicillin) }\end{array}$ & $\begin{array}{l}B . \\
\text { stearothermo } \\
\text { philus } \\
\text { (ATCC 7953) }\end{array}$ & $\begin{array}{l}\text { Yeast } \\
\text { extract, } \\
\text { peptone, } \\
\text { bacto agar, } \\
\text { dextrose }\end{array}$ & $\begin{array}{c}55^{\circ} \mathrm{C} \pm 1 \\
{ }^{\circ} \mathrm{C} \\
(16-18 \mathrm{~h})\end{array}$ \\
\hline $\begin{array}{l}\text { Tetracycline } \\
\text { (oxytetracycline) }\end{array}$ & $\begin{array}{l}\text { B. cereus } \\
\text { (ATCC } \\
11778 \text { ) }\end{array}$ & $\begin{array}{l}\text { Yeast } \\
\text { extract, } \\
\text { beef } \\
\text { extract, } \\
\text { peptone, } \\
\text { bacto agar }\end{array}$ & $\begin{array}{c}30^{\circ} \mathrm{C} \pm 1 \\
{ }^{\circ} \mathrm{C} \\
(16-18 \mathrm{~h})\end{array}$ \\
\hline $\begin{array}{l}\text { Aminoglycoside } \\
\text { (kanamycin) }\end{array}$ & $\begin{array}{l}\text { B. subtilis } \\
\text { (ATCC 6633) }\end{array}$ & $\begin{array}{l}\text { Beef } \\
\text { extract, } \\
\text { peptone, } \\
\text { bacto agar }\end{array}$ & $\begin{array}{c}36^{\circ} \mathrm{C} \pm \\
1^{\circ} \mathrm{C} \\
(16-18 \mathrm{~h})\end{array}$ \\
\hline $\begin{array}{l}\text { Macrolide } \\
\text { (tilosin) }\end{array}$ & $\begin{array}{l}\text { Kocuria } \\
\text { rizophila } \\
\text { (ATCC9341) }\end{array}$ & $\begin{array}{l}\text { Yeast } \\
\text { extract, } \\
\text { beef } \\
\text { extract, } \\
\text { peptone, } \\
\text { bacto agar, }\end{array}$ & $\begin{array}{c}36^{\circ} \mathrm{C} \pm \\
1{ }^{\circ} \mathrm{C} \\
(16-18 \mathrm{~h})\end{array}$ \\
\hline
\end{tabular}


glucose

ATCC: American Type Culture Collection

\section{RESULTS AND DISCUSSION}

Bioassay test (SNI 7424: 2008) was carried out on 24 egg samples taken from farmers and distributors to detect antibiotic residue. The test results are presented in Table 5, Table 6, and Table 7.

\section{TABLE 5. ANTIBIOTIC RESIDUE TEST RESULTS ON EGGS FROM FARMERS}

\begin{tabular}{|c|c|c|c|c|c|c|}
\hline $\begin{array}{c}\text { Egg } \\
\text { Origin }\end{array}$ & Sampling & $\mathrm{Am}$ & $\mathrm{Te}$ & $\mathrm{Pe}$ & $\mathrm{Ma}$ & $\begin{array}{c}\text { Positive } \\
\text { per Farmer }\end{array}$ \\
\hline Farmer & 1 & - & - & - & - & \multirow{6}{*}{7} \\
\hline \multirow[t]{5}{*}{1} & 2 & - & - & - & - & \\
\hline & 3 & + & - & - & - & \\
\hline & 4 & + & - & - & - & \\
\hline & 5 & + & + & - & - & \\
\hline & 6 & + & + & - & + & \\
\hline \multirow{6}{*}{$\begin{array}{c}\text { Farmer } \\
2\end{array}$} & 1 & - & - & - & - & \multirow{6}{*}{7} \\
\hline & 2 & + & + & - & - & \\
\hline & 3 & + & + & - & - & \\
\hline & 4 & - & - & - & - & \\
\hline & 5 & + & + & - & - & \\
\hline & 6 & + & - & - & - & \\
\hline \multirow{6}{*}{$\begin{array}{c}\text { Farmer } \\
3\end{array}$} & 1 & - & + & - & + & \multirow{6}{*}{9} \\
\hline & 2 & + & + & - & - & \\
\hline & 3 & + & - & - & - & \\
\hline & 4 & - & - & - & - & \\
\hline & 5 & + & + & - & - & \\
\hline & 6 & + & - & - & + & \\
\hline
\end{tabular}

(+): positive for antibiotic residue, (-): negative for antibiotic residue, Am: Aminoglycoside, Te: Tetracycline, Pe: Penicillin, Ma: Macrolide

The result showed that 13 out of 18 samples collected from farmers and 1 out of 6 samples collected from distributors were tested positive for antibiotic residues. Most of the tested positive samples contained aminoglycosides residue $(66.7 \%$ on eggs collected from farmers), followed by tetracycline residue $(44,4$ on farmers egg and $16,7 \%$ on distributors egg) and macrolide residue (16,7\% on farmers egg). All tested samples showed negative results for penicillin because its usage starts to subside. Penicillin can cause hypersensitivity in some animals [6].

\section{TABLE 6. ANTIBIOTIC RESIDUE TEST RESULTS ON EGGS FROM FARMERS}

\begin{tabular}{|c|c|c|c|c|c|c|}
\hline \multirow{2}{*}{$\begin{array}{l}\text { Egg } \\
\text { Origin }\end{array}$} & \multirow{2}{*}{$\begin{array}{c}\text { Sampli } \\
\text { ng }\end{array}$} & \multicolumn{4}{|c|}{ Antibiotic Class } & \multirow{2}{*}{$\begin{array}{c}\text { Total } \\
\text { Positive per } \\
\text { Distributor }\end{array}$} \\
\hline & & $\mathrm{Am}$ & $\overline{\mathrm{Te}}$ & $\mathrm{Pe}$ & $\mathrm{Ma}$ & \\
\hline \multirow{2}{*}{$\begin{array}{l}\text { Distributor } \\
1\end{array}$} & 1 & - & - & - & - & \multirow{2}{*}{0} \\
\hline & 2 & - & - & - & - & \\
\hline \multirow{2}{*}{$\begin{array}{l}\text { Distributor } \\
2\end{array}$} & 1 & - & - & - & - & \multirow{2}{*}{0} \\
\hline & 2 & - & - & - & - & \\
\hline \multirow{2}{*}{$\begin{array}{l}\text { Distributor } \\
3\end{array}$} & 1 & - & - & - & - & \multirow[b]{2}{*}{1} \\
\hline & 2 & - & + & - & - & \\
\hline
\end{tabular}

(+): positive for antibiotic residue, (-): negative for antibiotic residue, Am: Aminoglycoside, Te: Tetracycline, Pe: Penicillin, Ma: Macrolide

TABLE 7. PERCENTAGE OF POSITIVE RESULT PER CLASS OF ANTIBIOTICS

\begin{tabular}{lcc}
\hline \multicolumn{1}{c}{ Egg Origin } & Farmers & Distributors \\
\hline $\begin{array}{l}\text { Antibiotic } \\
\text { Class }\end{array}$ & & \\
\hline Aminoglycoside & $66.7 \%$ & $0 \%$ \\
Tetracycline & $44.4 \%$ & $16.7 \%$ \\
Macrolide & $16.7 \%$ & $0 \%$ \\
Penicillin & $0 \%$ & $0 \%$ \\
\hline
\end{tabular}

\section{Discussion}

Chowdhury et al., (2015) detected tetracycline residue in $25 \%$ commercial poultry farm and $7 \%$ in local scavenging. In Indonesia, Utari et al., (2018) did screening tests using active chicken egg samples that 
were randomly collected from various province in Indonesia and found that in 2017 as much $0,75 \%$ of the samples were positive for aminoglycoside residue, $0,13 \%$ positive for tetracycline residue and macrolide. The positive results refer to the main causative factor, which is the irrationally use of antibiotics [2][7][8][9]. This lot of positive results raises concerns about the health of people who consume eggs.

Based on the questioner that was given to the farmer, all 3 farmers did not apply withdrawal time period when the animal was under antibiotic treatment. On the other hand, farmer 3 does different feeding, where the samples taken from there showed more positive results compared to the other two farmers. According to Muaz et al (2018), antibiotic administration in poultry is divided into three categories, namely therapeutic to treat bacterial infections, prophylactic to prevent disease, and growth promoters (AGP) to enhance the growth rate. The administration of antibiotics as AGP is applied through feed to all the animals in a long period of time but the dosage given is less than the therapeutic purpose; therefore, longer withdrawal time period is required. Mund et al (2016) explained that the continuously usage of veterinary drugs, including antibiotics, with doses that are not appropriate and not followed by withdrawal time increases the possiblity of drugs' residue deposition in animal's ediable tissue, including egg. However, some samples tested negative for antibiotic residues. This could happen because each animal has different metabolic rate. The enzyme systems that play role in drug metabolism, cytochrome P-450 (CYP450), have different rate from one individual to another. In addition, aging could reduce the liver's capacity for metabolism through CYP450 [10].

In general, antibiotics are safe to use in medicine for animals and humans. Nevertheless, improper use of antibiotics such as inaccurate dosage or use of antibiotics as a prevention and not treatment could instigate health problems. Antibiotic residue in animal-originated food that exceeds its maximum residue limit (MRL) has become a concern to the public health [11]. Existence of it in animal-originated food can cause allergy reaction, chronic toxicology, mutagenic, carcinogenic, reproductive abnormalities and weakness of fetus development, hepatotoxity, bone marrow toxicity, nephropathic and disruption of normal flora in digestive system [4][7][11].

Bacteria have several resistance mechanisms to antibiotics for their survival. Resistance mechanism is a complex mechanism, differs from one bacterium to another, it also influenced by the class of antibiotics that being used [12]. The mechanism of resistance includes efflux system, limiting access to antibiotics by bacterial cell walls, the use of enzymes to destroy or damage antibiotics, the occurrence of target mutations from antibiotics and mutations of ribosomes that produce new proteins so that antibiotics do not recognize them [13]. Lin et al., (2015) suggests that there are many efflux systems used by bacteria for they have many different genomics. A transcriptional regulator that can suppress or activate genes transcription controls the efflux system.

Several mechanisms of aminoglycoside resistance are modification of aminoglycoside by bacteria-produced enzymes or called aminoglycosidemodifying enzymes (AMEs), ribosome mutation that prevent the drug to bind, and rejection from inside the cell by active efflux system. The most common mechanism is modification of aminoglycoside by the AMEs. Three class of known AMEs are acyl-coenzym Adependent acetyltransferases (AAC), nucleoside triphosphate-dependent nucleotidyl transferases (ANT), and nucleoside triphosphate-dependent phosphotransferases (APHs). These enzymes along with other mechanism works 
to inactivate aminoglycoside [12][14]. The repeated use of aminoglycosides will regulate the chromosomes to encode the multidrug efflux system [15].

Tetracycline resistance has a similar mechanism to aminoglycoside resistance. Bacteria resistant to tetracycline have feature such as tetracycline-specific efflux that can pumps out tetracycline out of the cell, ribosome mutation binding-site, and also usage of bacteria-produced enzymes to change or destroy the drug called tetracycline-modifying enzymes. Another resistance mechanism is by using proteins that protects ribosomes. These proteins are called tetracycline ribosomal protection proteins (RPPs) work specifically to release tetracycline from ribosome membrane [16][17].

Fyfe at al. (2016) explained macrolide resistance mechanism includes several mutations carried out by bacteria to modify ribosomes such as 23S rRNA mutations, ribosomal proteins mutations, and erm genes that mediates additional of methyltransferases on 23S rRNA. Macrolide resistance also has efflux system and enzymatic inactivation by macrolide esterases and macrolide phosphotransferase.

Antibiotic residues also contaminate environment, cause structural and abundance change of the soil, disturbing the environmental microbes. The most dangerous effect is the development of resistant bacteria to antibiotic and its transfer to consumers. Environmental bacteria can also transform into resistance in the event it constantly exposed by antibiotic residue [18]. The occurring development of antibiotic resistance genes in bacteria is reported because antibiotics are used too often throughout the world, especially in livestock [8][18].

Resistant bacteria can contaminate environment through livestock's feces and urine [18][19]. According to Centers for Disease Control and Prevention (CDC) data in 2013, as much as 18 antibiotic-resistant bacteria have been detected. These bacteria are Clostridium difficile, CarbapenemResistant Enterobactericeae (CRE), Neisserua gonorrhoeae, MultidrugResistant Acinobacter, Drug-Resistant Campylobacter, Extended Spectrum bLactamase (ESBL) producing Enterobateriaceae, Vancomycin-Resistant Enterococcus (VRE), Drug-Resistant NonTyphoidal Salmonella, Drug-Resistant Shigella, Methicillin-Resistant Staphylociccus Aureus (MRSA), Stereptociccus Pneumoniae, Drug-Resistant Tuberculosis.

In contrast to egg samples from farmers, samples collected from distributors showed less positive result. This can occur due to possible heat factor obtained during transportation and in storage room of these eggs. According to research conducted by Mosha (2017), the residual levels of tetracycline in tested egg samples were reduced after boiling eggs at temperature of $85-95^{\circ} \mathrm{C}$ for 10 minutes and fried at temperature of $110-130^{\circ} \mathrm{C}$ for 2 minutes. The degradation happened because tetracycline has structure that is not stabile when heated. Temperature and duration of heating are the most important factors in residual degradation of tetracycline. This also applies to penicillin and macrolide residues [20]. Up to date, the stability of aminoglycoside residue is not known precisely [18]. Study done by Mahmoud et al (2015) showed loss of gentamicin residue in chicken meat after being boiled and fried for 10 minutes. Antibiotic residue degradation occurs due to the transfer of residue from chicken to cooking media such as water and oil. The usage of aminoglycoside in animal feed has been banned in several countries. Aminoglycoside has prolonged postantibiotic effect (PAE) [21]. Beside temperature and heating duration, other factors such as $\mathrm{pH}$, food matrix, and cooking procedure plays role in antibiotic residues degradation in eggs or other animal-originated food [22]. 


\section{CONCLUSSION}

Total positive samples for antibiotic residue were 14 out of 24 samples. Antibiotic residues at the ditributors were less compared to farmers. Detection of antibiotic residue proves that irrational use of antibiotics in livestock is still happening. Lack of withdrawal time period in underantibiotic-treatment animal also contribute to this detection.

Supervision of veterinary drugs usage, especially antibiotics, needs an improvement. Increasing awareness of the importance of withdrawal time to the farmers will contribute much in providing better animal food to the consumers. Further research and data collection need to be carried out to determine the exact cause of the change in positive samples at distributors. In addition, usage of nonAGP products in animal feed can be used as an alternative.

\section{REFERENCES}

[1] Winarno, F.G. 1996. UndangUndang tentang pangan. Kumpulan Makalah pada Musyawarah II dan seminar Ilmiah Persatuan Ahli Teknologi Laboratorium Kesehatan Indonesia.

[2] Bahri S., Indraningsih, R. Widiastuti, T.B Murdiati dan R. Maryam. 2002. Keamanan pangan asal ternak: Suatu tuntutat di era perdagangan bebas. Wartazoa 12.

[3] Bahri S., E. Masbulan, A. Kusumaningsih. 2005. Proses Praproduksi sebagai Faktor Penting dalam Menghasilkan Roduk Ternak yang Aman untuk Manusia. Jurnal Litbang Pertanian 24.
[4] Nisha A.R. 2008. Antibiotic Residues - A Global Health Hazard. Veterinary World. Vol.1. No.12.

[5] Dewi A.A.S., N.P. Widdhiasmoro, I. Nurlatifah, N. Riti, dan D. Purnawati. 2014. Residu Antibiotika Pada Pangan Asal Hewan, Dampak dan Upaya Penanggulangannya. Buletin Veteriner. Vol. 26. No. 85. BBVet Denpasar.

[6] Omidi A. 2009. Anaphylactic Reaction in a Cow Due to Parenteral Administration of PenicillinStreptomycin. The Canadian Veterinary Journal. Vol. 50 (7).

[7] Mund M.D., U.H. Khan, U. Tahir, B.E. Mustafa, A. Fayyaz. 2017. Antimicrobial Drug Residues in Poultry Products and Implications on Public Health: A Review. International Journal of Food Properties.Vol. 20.

[8] World Health Organization (WHO). 2017. Facts about Antimicrobial Resistance.

[9] Muaz K., M. Riaz, S. Akhtar, S. Park, A. Ismail. 2018. Antibiotic Residues in Chicken Meat: Global Prevalence, Threats, and Decontamination Strategies: A Review. Journal of Food Protection.Vol. 81.

[10] Le, J. 2019. Pharmacokinetics Drug Metabolism. Merck Manual.

[11] Mosha J.C. 2017. Tetracycline Residues in Raw and Cooked Chicken Eggs in Tanzania: A Case Study of Dar Es Salaam. Sokoine University of Agriculture. Morogoro, Tanzania.

[12] Lin, J., K. Nishino, M.C. Roberts, M. Tolmasky, R.L. Aminov, L. Zhang. 2015. Mechanism of Antibiotic Resistance. Frontiers in Microbiology.

[13] Centers for Disease Control and Prevention (CDC). 2018. How 
Antibiotic Resistance Happens. Antibiotic / Antimicrobial Resistance (AR / AMR).

[14] Shi K., S.J. Caldwell, D.H. Fong, A.M. Berghuis. 2013. Prospects for Circumventing Aminoglycoside Kinase Mediated Antibiotic Resistance. Frontiers and Cellular and Infection Microbiology.

[15] Poole, K. 2011. Pseudomonas aeruginosa: resistance to the max. Frontiers in microbiology. Vol. 2.

[16] Li, W. G.C. Atkinson, N.S. Thakor, U. Allas, C-C. Lu, K-Y. Chan, T. Tenson, K. Schulten, K.S. Wilsom, V. Hauryliuk, J. Frank. July 2013. Mechanism of Tetracycline Resistance by Ribosomal Protection Protein Tet $(o)$. Nature Communications.

[17] Grossman T.H. 2016. Tetracycline Antibiotics and Resistance. Cold Spring Harbor Perspective in Medicine.

[18] Jayalakshmi K., M. Paramasivam, M Sasikala, T.V Tamilam, A.
Sumithra. 2017. Review on Antibiotic Residues in Animal Products and its Impact on Environments and Human Health. Journal of Entomology and Zoology Studies.

[19] Centers for Disease Control and Prevention (CDC). 2018. Food and Food Animals. Antibiotic / Antimicrobial Resistance (AR / AMR).

[20] Heshmati A. 2015. Impact of Cooking Procedures on Antibacterial Drug Residues in Foods: A Review. Journal of Food Quality and Hazards Control.

[21] Krause K.M., A.W. Serio, T.R. Kane, L.E. Connolly. 2016. Aminoglycosides: An Overview. Cold Spring Harbor Perspectives in Medicine.

[22] Tien L. 2016. Thermal Degradation of Antibiotic Residues: Amphenicols as a Case Study. McGill University Montreal, Canada. 